\title{
Pengembangan Model Web Based Learning Tools
}

\author{
Maspaeni ${ }^{1}$, Lalu Moh. Nurkholis ${ }^{2}$, Basuki Wibawa ${ }^{3}$ \\ STMIK Mataram ${ }^{1}$ \\ ASM Mataram² \\ Universitas Negeri Jakarta ${ }^{3}$ \\ maspaeni@gmail.com¹
}

\begin{abstract}
Abstrak - Salah satu parameter yang digunakan untuk mengukur kualitas organisasi pendidikan adalah pemanfaatan dan penggunaan teknogi informasi. Pemanfaatan dan penggunaan teknologi informasi yang tepat dapat meningkatkan kualitas pendidikan, salah satunya dengan memilih atau menerapkan sistem pembelajaran yang tepat. Penerapan sistem pembelajaran berbasis web ini merupakan salah satu teknologi informasi yang dapat meningkatkan kualitas pendidikan ataupun menjadi solusi dalam sistem pembelajaran. Penerapan sistem pembelajaran berbasis web ini adalah dengan memanfaatkan sebuah alat atau sistem pembelajaran dengan menggunakan aplikasi Course Managemen System (CMS)/Learning Managemen System (LSM) atau yang disebut dengan web based learning too/s. Beberapa aplikasi CMS/LMS (web based learning tools) yang dapat digunakan untuk menerapkan sistem pembelajaran berbasis web ini adalah Moodle, Edmodo, Schoology, Google Classroom, Blackboard, Articulate, WebCT dan lain-lain. Penerapan sistem pembelajaran dengan menggunakan web based learning tools ini, tentunya memiliki kelebihan dan kelemahan masing-masing baik dari segi interface ataupun managemen konten. Untuk itu, dalam ini akan dikaji atau dianalisis perilaku pengguna dalam penggunaan 3 buah web based learning tools yaitu Moodle, Edmodo dan Schoology guna mengetahui ketertarikan pengguna mengenai interface dari ke 3 web based learning tools tersebut. Dengan demikian, berdasarkan ketertarikan user/pengguna ini, akan dikembangkan model sebuah web based learning tools yang diharapkan dapat digunakan untuk meningkatkan kualitas proses pembelajaran.
\end{abstract}

Keyword: web based learning tools, LMS, pembelajlaran.

\section{Pendahuluan}

Salah satu teknologi yang berkembang begitu cepat saat ini adalah teknologi informasi. Teknologi informasi ini sangat dekat dengan kehidupan manusia dan sudah menjadi sebuah kebutuhan yang tak terelakan, karena keberadaan dan manfaatnya sudah dirasakan oleh semua kalangan baik organisasi ataupun individu. Salah satu organisasi yang merasa sangat diuntungkan dengan keberadaan teknologi informasi ini adalah organisasi pendidikan, seperti sekolah-sekolah, lembaga pelatihan ataupun perguran tinggi.

Salah satu parameter yang digunakan untuk mengukur kualitas organisasi pendidikan adalah pemanfaatan dan penggunaan teknogi informasi. Pemanfaatan dan penggunaan teknologi informasi yang tepat dapat meningkatkan kualitas pendidikan, salah satunya dengan memilih atau menerapkan sistem pembelajaran yang tepat pula. Selain itu, teknologi informasi dapat juga menjadi solusi dalam menangani masalah pendidikan yang terkendala dengan jarak, waktu, biaya, sumber daya manusia dan lain sebaginya. Salah satu teknologi informasi yang dapat meningkatkan kualitas pendidikan ataupun menjadi solusi dalam sistem pembelajaran adalah dengan menerapkan sistem pembelajaran berbasis web. Penerapan sistem pembelajaran berbasis web ini sudah diterapkan oleh banyak organisasi pendidikan termasuk STMIK MATARAM. Sistem pembelajaran berbasis web ini adalah sebuah alat atau sistem pembelajaran dengan menggunakan aplikasi Course Managemen System (CMS)/Learning Managemen System (LSM) atau yang disebut dengan web based learning tools. Beberapa aplikasi CMS/LMS (web based learning tools) yang dapat digunakan untuk menerapkan sistem pembelajaran berbasis web ini adalah Moodle, Edmodo, Schoology, Google Classroom, Blackboard, Articulate, WebCT dan lain-lain.

Penerapan sistem pembelajaran dengan menggunakan web based learning tools ini, tentunya memiliki kelebihan dan kelemahan masing-masing baik dari segi interface ataupun managemen konten. Untuk itu, dalam ini akan dikaji terhadap perilaku pengguna dalam penggunaan 3 buah web based learning tools yaitu Moodle, Edmodo dan Schoology guna mengetahui ketertarikan pengguna mengenai interface dari ke 3 web based learning tools tersebut. Dengan demikian, berdasarkan ketertarikan user/pengguna ini, akan dikembangkan sebuah model web based learning tools yang dapat digunakan untuk mengembangkan proses pembelajaran di STMIK MATARAM. 


\section{Literatur Review}

\section{1) Web Based Learning}

Web Based Learning merupakan pembelajaran berbasis web (e-learning) yang mempunyai tiga faktor utama yaitu pedagogy, content dan technologiy. Faktor yang satu dengan laninya dalam mendesain E-learning saling mempengaruhi. Adapun faktor utama yang perlu diperhatikan dalam menerapkan sistem pembelajaran berbasis web adalah pedagogy, teknologi dan content seperti terlihat pad gambat 1 berikut:

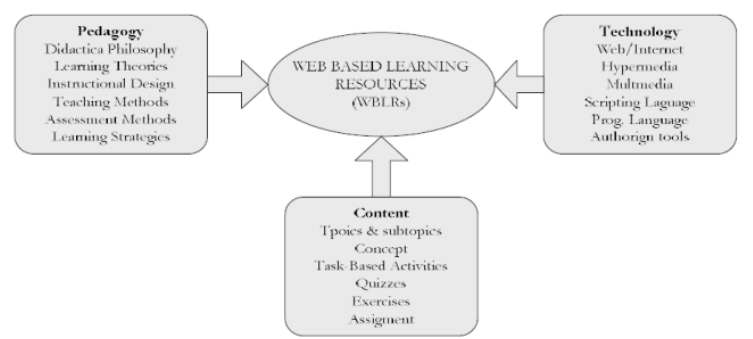

Gambar 1. Faktor Utama Sistem Pembelajaran Berbasis WEB. (Marpanaji 2012)

a) Edmodo

Edmodo merupakan platform atau tools dari sistem pembelajaran berbasis web (web based learning tools) dengan pembelajaran berbasis jejaring sosial yang diperuntukan untuk guru, murid sekaligus orang tua murid yang dikembangkan oleh oleh Nic Borg dan Jeff O'hara pada akhir tahun 2008. (Nu'man 2014). Berikut adalah tampilan LMS Edmodo seperti pada gambar 2 .

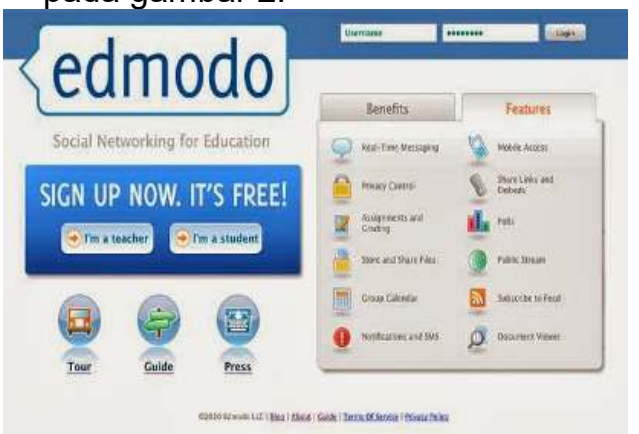

Gambar 2. LMS Edmodo

b) Schoology

Menurut Aminoto (2014) Schoology adalah website yang memadu elearning dan jejaring sosial. Berikut adalah bentuk tampilan dari LMS Schoology seperti pada gambar 3 .

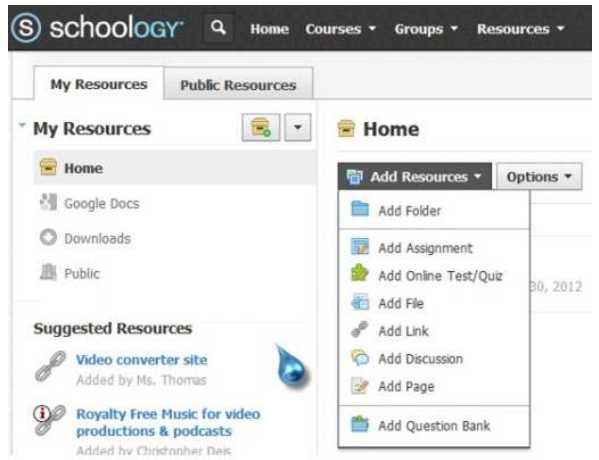

Gambar 3. LMS Schoology

c) Moodle

Moodle merupakan Course Management System (CMS) yang dapat digunakan untuk membantu pendidik dalam membuat suatu kursus online. (Marpanaji 2012). Berikut adalah tampilan dari LMS Moodle seperti pada gambar 4 .

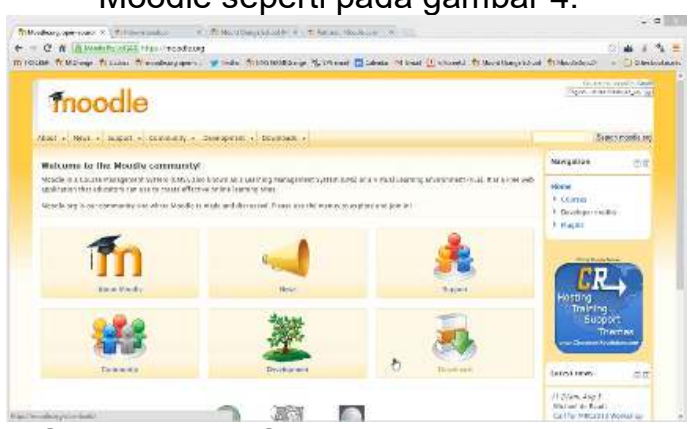

Gambar 4. LMS Moodle

2) Learning Managemen System Learning Managemen System adalah suatu sistem yang mampu mengelola pembelajaran secara online dalam proses penyelengaraan e-learning. (Marpanaji 2012).

3) E-learning

E-learning dapat diterjemahkan sebagai pembelajaran yang menggunakan perangkat eletronik sebagai medianya. E-learning merupakan seperangkat aplikasi dan proses yang dibuat untuk kegiatan pembelajaran. Elearning lebih mengarah kepada kelas virtual (Virtual Classroom). Materi-materi dalam kegiatan pembelajaran elektronik tersebut kebanyakan dihantarkan melalui media internet, intranet, tape, audio maupun video, satelit, televisi interaktif, ataupun media penyimpanan seperti CDROM. (Aminoto 2014).

Dari beberapa penelitian yang sudah dilakukan diantaranya mengenai evaluasi penggunaan sistem pembelajaran berbasis web yang lebih user friendly dan lebih dibutuhkan oleh pengguna, maka dalam hal ini akan dilakukan analisis/pengkajian perilaku 
pengguna terhadap 3 buah alat atau tools dari sistem pembelajaran berbasis web yaitu Moodle, Edmodo dan Schoology (ontologi) mengenai letak ketertarikan pengguna terhadap semua fitur atau fasilitas-fasilitas yang disedikan oleh ke tiga tools tersebut, yang dapat membuat pengguna lebih nyaman dan menarik baik dari segi interfacenya maupun dari segi kontennya, sehingga dari hasil kajian perilaku pengguna ini akan rancang sebuah tools sistem pembelajaran berbasis web yang nantinya dapat diterapkan sebagai sistem pembelajaran berbasis web di kampus STMIK MATARAM (efistomologi) dan diharapkan dapat digunakan untuk mengembangkan proses pembelajaran di STMIK MATARAM yang lebih berkualitas. (aksiologi)

\section{Hasil Penelitian yang relevan}

Beberapa hasil penelitian yang relevan dengan artikel ini adalah penelitian tentang Choosing a Web-Based Learning Tool: Focussing on the Needs of Users (Alexander 2006), dimana dalam penelitian ini adalah melakukan kajian terkait pemilihan sebuah sistem pembelajaran berbasis web yang lebih dibutuhkan oleh user terutama mahasiswa yang ada di Universitas University of Technology, Sydney (UTS) terhadap 3 buah web based learning tools yaitu: Courselnfo Version 4.06, WebCT Version 2.0 dan TopClass Version 3.1. Dari hasil kajian penelitian ini diperoleh bahwa Courselnfo Version 4.06 merupakan web based learning tools yang paling dibutukan dengan kelebihannya dalam hal adanya fasilatas pelayanan pengiriman dan penerimaan pesan/komentar pribadi dari atau ke para murid/siswa.

Sedangkan penelitian dengan judul Evaluating the Usability of Web-based Learning Tools (Wang 2002) adalah melakukan evaluasi atau penilaian terhadap 2 buah web based tools yaitu WebCT dan Blackboard dengan hasil bahwa Blackboard secara keseluruhan dianggap lebih mudah digunakan oleh instruktur dan administrator daripada WebCT, akan tetapi Blackboard tidak menyediakan antarmuka/user interface yang sesuai pengguna sedangkan WebCT, lebih disesuaikan dengan pengguna.

Dari beberapa penelitian di atas, yaitu mengenai evaluasi web based learning tools yang lebih baik dari beberap web based learning tools yang ada, maka dalam hal ini, akan dilakukan analisis/kajian terhadap perilaku pengguna menggunakan 3 buah web based learning tools yang ada mengenai ketertarikannya terikat fitur atau fasilitasfasilatas yang tersedia dan membuat pengguna lebih nyaman dan lebih menarik dari web based learning tools yang ada seperti Moodle, Edmodo dan Schoology baik dari sisi interface maupun kontennya.

Berikut adalah gambaran mengenai user modeling yang akan dibuat berdasarkan kajian perilaku pengguna dalam penggunaan web based learning tools yaitu Moodle, Edmodo dan Schoology yang di adopsi.

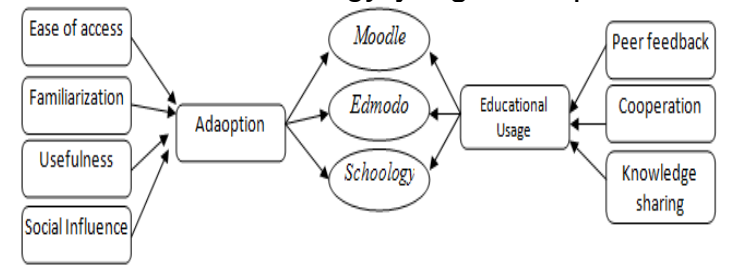

Gambar 5. Adoption and Educational usage of Moodle, Edmodo and Schoology

\section{Kesimpulan}

Web based learning adalah sebuah sistem pembelajaran yang berbasis web (elearning) dengan menggunakan suatu tools atau aplikasi yang dapat digunakan untuk mengelola atau mengatur sistem pembelajaran berupa materi, tugas, quiz, diskusi dan lain-lain. Adapun tools atau aplikasi-aplikasi itu disebut dengan Learning Managemen System (LMS) atau Course Managemen System (CMS) seperti Moodle, Edmodo dan Schoology. Berdasarkan analisis perilaku pengguna terhadap penggunaan ke tiga LMS/CMS tersebut akan dirancang/dibuat sebuah LMS (tools) berdasarkan ketertarikan pengguna dari ketiga LMS tersebut baik dari segi interface maupun dari segi kontennya yang diharapkan dapat mengembangkan proses pembelajaran di STMIK MATARAM.

\section{Referensi}

Alexander, James Sawers and Shirley. 2006. Choosing a Web-Based Learning Tool: Focussing on the Needs of Users. Sydney, AUSTRALIA: Institute for Interactive Media and Learning The University of Technology.

Aminoto, Tugiyo dan Hairul Pathoni. 2014. "Penerapan Media E-Learning Berbasis Schoology Untuk Meningkatkan Aktivitas Dan Hasil Belajar Materi Usaha Dan Energi Di Kelas XI SMA N 10 Kota Jambi." Sainmatika Vol. 8.(1).

Marpanaji, Zyainuri dan Eko. 2012. Penerapan ELearning MOODLE Untuk Pembelajaran Siswa Yang Melaksanakan Prakerin. Yogyakarta: Jurnal Pendidikan Vokasi. Yogyakarta: Fakultas Teknik Universitas Negeri Yogyakarta.

Nu'man, Ahmad Zanin. 2014. "Efektifitas Penerapan E-Learning Model EDMODO Dalam Pembelajaran Pendidikan Agama 
Islam Terhadap Hasil Belajar Siswa (Studi

Kasus : SMK Muhammadiyah 1 Sukoharjo)."

Duta.com Volume $7 \mathrm{~N}$.

Wang, M.-A. Storey B. Phillips M. Maczewski M. 2002. Evaluating the Usability of Web-Based Learning Tools. British Columbia, Canada: Departments of Computer Science and Psychology University of Victoria. 